\title{
A SUMMARY OF ENVIRONMENTAL HEALTH STUDIES IN THE CITY OF OSTRAVA AND THE SURROUNDING REGION IN THE CZECH REPUBLIC
}

\author{
Hana Tomášková1, 2, Ivan Tomášek ${ }^{1,2}$, Pavla Polaufová2, Hana Šlachtová1, Jana Janoutová1, Vítězslav Jiřík', \\ Vladimír Janout ${ }^{1}$ \\ ${ }^{1}$ Department of Epidemiology and Public Health, Faculty of Medicine, University of Ostrava, Ostrava, Czech Republic \\ ${ }^{2}$ Institute of Public Health in Ostrava, Ostrava, Czech Republic
}

\section{SUMMARY}

Aim: This study is concerned with environmental health studies conducted in Ostrava (Czech Republic) and the surrounding region since the early nineties.

Methods: Various databases, journals and reports, including internal or unpublished reports, were reviewed to assess the individual publications. A brief description of the studies and main results were collated.

Results: The city of Ostrava and the surrounding region is an important industrial centre in the Czech Republic with a long-term heavy environmental and occupational disease burden. In spite of the theoretically assessed decline of health risks related to decreasing concentrations of compounds in the environment in recent years, it still poses a disproportionally high risk for the city residents. There are a number of studies suggesting supportive evidence, but they are highly variable in their approach to this topic resulting in a high uncertainty of observed associations and consistency of results. Most of the studies were focused on specific contexts, without any relation to environmental factors.

Conclusions: A more systematic approach is needed to assess environmental health burden of diseases especially in relation to air pollution, based on the prospective cohort study, that would lead to sufficient new evidence for accurate and updated description of the environmental health burden in Ostrava.

Key words: industry, air pollution, $\mathrm{PM}_{10}$, health

Address for correspondence: H. Tomášková, University of Ostrava, Syllabova 19, 70300 Ostrava, Czech Republic. E-mail: hana.tomaskova@ osu.cz

http://dx.doi.org/10.21101/cejph.a4537

\section{INTRODUCTION}

Ostrava is the third largest city in the Czech Republic, located in the north-east of the Czech Republic. Together with the neighbouring city of Karviná it forms the Ostrava-Karviná region. Since the early nineteenth century it has been known as an important industrial centre in Central Europe and also one of the worst places in term of environmental degradation due to the presence of heavy industry - mainly mines, coke ovens, metallurgical and chemical plants (1) (Fig. 1).

Industrial development started by a discovery of coking coal and continued for another two centuries regardless of the actual political and social situation. This initially small town was transformed into an industrial giant, causing a housing crisis due to a population boom. The new residential areas surrounded industrial areas, originally built at the edge of the city. It has since merged to form one continuous urban and industrially developed area, that is not common in other cities (Fig. 2).

At least six generations have been affected by high concentrations of pollutants in the ambient air in the city and in the region. No doubt it is a unique situation in term of the magnitude and duration of the population exposure (as discussed in detail in other articles in this Supplement). Worldwide, only a few places

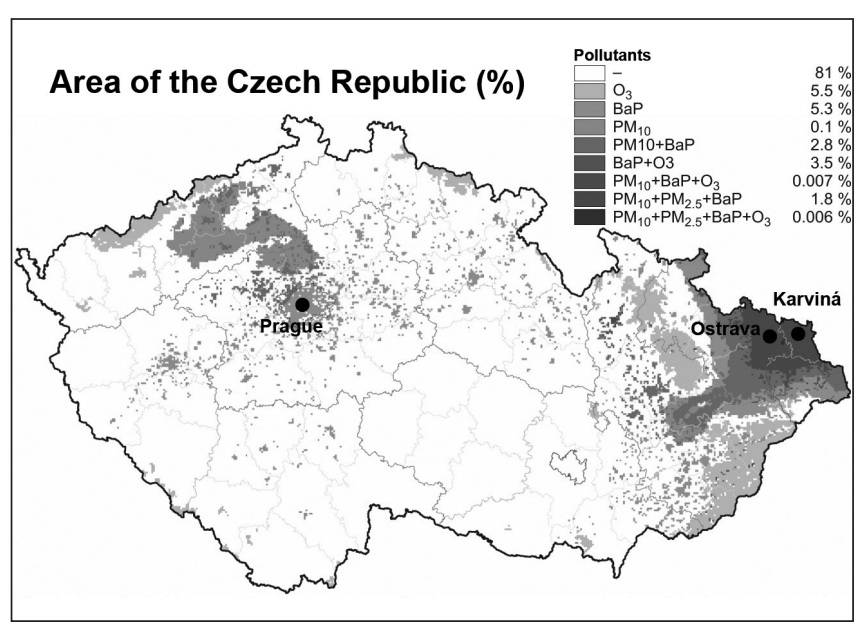

Fig. 1. Areas with exceeding of the health protection limit values for selected groups of pollutants, 2014 (Source: Czech Hydrometeorological Institute). 


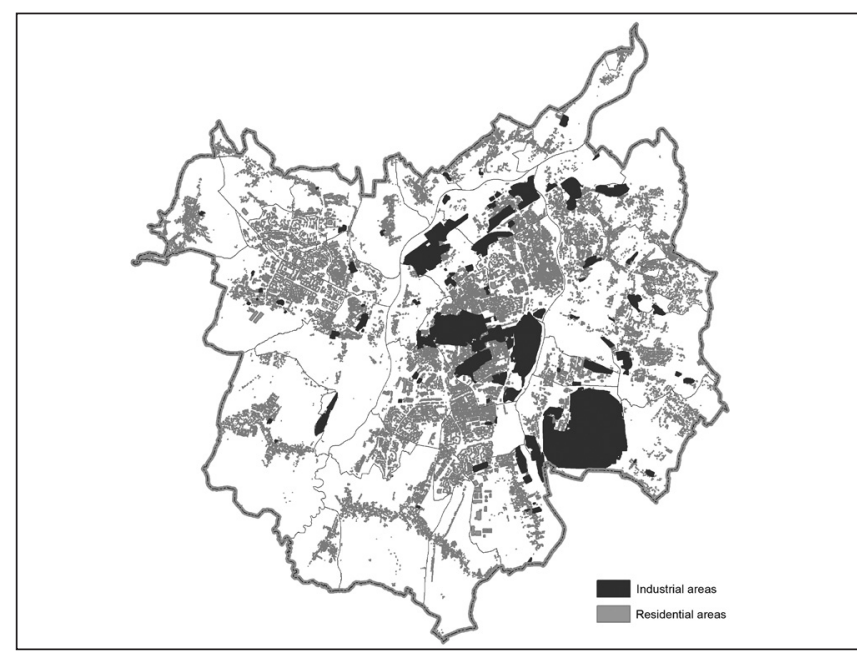

Fig. 2. Merging industrial and residential areas in Ostrava.

could be found with such duration and level of population exposure. Historical levels of exposure are not known because there was no air quality monitoring at that time, but it can be assumed because of the 300 and more mines located in Ostrava during the Austro-Hungarian Empire, each with its own coke oven emitting harmful substances into the atmosphere. Fig. 3 clearly illustrates the situation in Ostrava in the mid-20th century.

Since the 1920's degradation of the environment deteriorated dramatically due to continuing industrial development, exceeding the prospects of implemented mitigation measures - for example subsidence associated with mining activity which practically erased a part of the historical city centre from maps, or the burning heaps associated with coal and metallurgical activities and contamination of large areas by the chemical industry throughout the city, which currently threaten important groundwater resources.

The pressure on polluters has been increasing since the late 1990's. New scientific viewpoints regarding the health aspects of environmental pollution, especially air pollution, led to increasing concern from the public. Applied pollution prevention and mitigation measures together with closures of inefficient mines, ironworks and other heavy industries contributed to a significant decline of air pollution levels in Ostrava and surrounding region. However, this decline is still largely inadequate when compared to other European states and regions. Nowadays, in spite of the significant reduction in numbers of factories a considerable number of them still remains in operation, contributing to the unsatisfactory situation in the city and the region. Old buildings often constrain the installation of the best available technologies.

The World Health Organization (WHO) reports, that population health status is affected by lifestyle factors $(50 \%)$, environmental factors $(20 \%)$, genetic factors $(10-15 \%)$ and the level of health care (10-15\%) (2). Consequently, over one-fifth of the total disease burden that can be associated with hazards related to risk factors originating in the environment. This is, however, a considerably simplified view, because the individual determinants interact and act in a comprehensive manner. Environmental degradation, exposure to air pollution, social instability, unhealthy lifestyles and hard living conditions have combined in Ostrava and the region since the very beginning, affecting local population health and resulting in higher prevalence of cardiovascular disease, incidence of cancers and diabetes (Table 1,2).

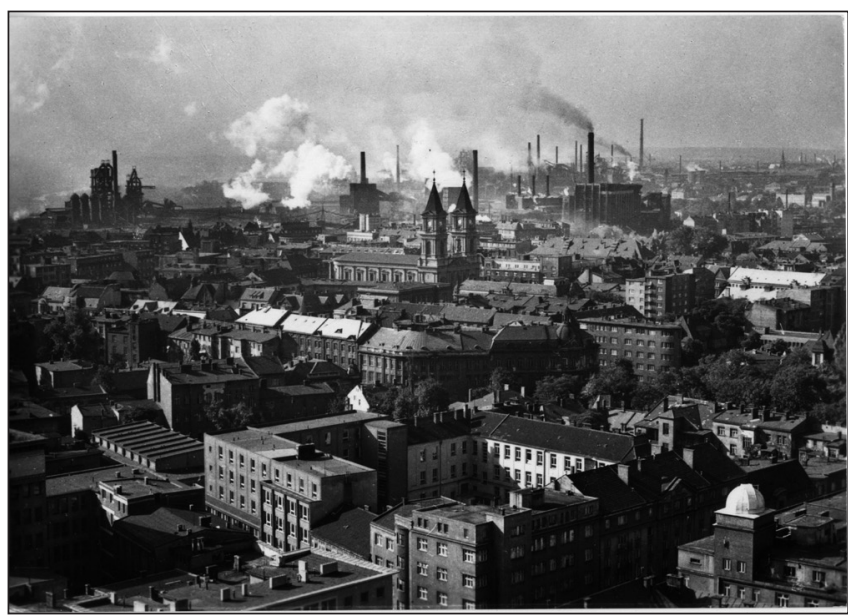

Fig. 3. The panorama of Ostrava in the mid-20th century (Source: The Ostrava City hall Archiv).

A number of risk factors is associated with disease burden. Of these, particularly in Ostrava and the region, it has been clearly demonstrated that elevated long-term inhalation exposure of the population to aerosol $\left(\mathrm{PM}_{10} / \mathrm{PM}_{2.5}\right)$ and carcinogens compared to the rest of the country results in a quantified health risk of mortality and morbidity and the development and prevalence of cancers (3).

The aim of the summary is to provide an overview and description of projects on environmental pollution and human health that have been implemented and carried out in Ostrava and the region since the early nineties.

\section{MATERIALS AND METHODS}

Studies were obtained from databases, scientific journals and reports.

Multiple sources of information were collated including routinely collected national or special monitoring data, and results of international and other studies.

\section{RESULTS}

\section{Routinely Collected Data}

In general, routinely collected data are easily accessible on internet as yearbooks for the Czech Republic or the individual regions, published by the Institute of Health Information and Statistics (IHIS) (4). Based on the analyses of routinely collected statistical data Ostrava (the district) ranks among the places with the worst health status in the Czech Republic.

Comparison of indicators of population health status in Ostrava district with the rest of the Czech Republic shows a life expectancy in Ostrava of 72.4 years for men and 79.4 years for women (average values for the period 2006-2010) about 1.5, respectively 0.7 years less than the national average (a downtrend over the last 40 years in the Czech Republic). Also, the specific mortality for cardiovascular diseases (the cause of half of all deaths) exceeds the average value in the Czech Republic. Cancer mortality (the second most frequent cause that represents a quarter of all deaths in the Czech Republic) is slightly higher and cancer incidence in 
Table 1. Standardized mortality index of total and specific mortality in the district of Ostrava in comparison with the Czech Republic (Source: Institute of Health Information and Statistics of the Czech Republic)

\begin{tabular}{|c|c|c|c|c|c|c|c|c|c|}
\hline \multirow{2}{*}{\multicolumn{2}{|c|}{$\begin{array}{l}\text { Indicator } \\
\text { Gender }\end{array}$}} & \multicolumn{2}{|c|}{ Total mortality } & \multicolumn{2}{|c|}{ Cancer mortality } & \multicolumn{2}{|c|}{ CVD mortality } & \multicolumn{2}{|c|}{$\begin{array}{l}\text { Respiratory diseases } \\
\text { mortality }\end{array}$} \\
\hline & & \multirow{2}{*}{$\begin{array}{l}\text { Male } \\
110 \%\end{array}$} & \multirow{2}{*}{$\begin{array}{c}\text { Female } \\
109 \%\end{array}$} & \multirow{2}{*}{$\begin{array}{l}\text { Male } \\
120 \%\end{array}$} & \multirow{2}{*}{$\begin{array}{c}\text { Female } \\
112 \%\end{array}$} & \multirow{2}{*}{$\begin{array}{l}\text { Male } \\
102 \%\end{array}$} & \multirow{2}{*}{$\begin{array}{c}\text { Female } \\
103 \%\end{array}$} & \multirow{2}{*}{$\begin{array}{l}\text { Male } \\
132 \%\end{array}$} & \multirow{2}{*}{$\begin{array}{c}\text { Female } \\
138 \%\end{array}$} \\
\hline \multirow{13}{*}{ ‡্ } & 2001 & & & & & & & & \\
\hline & 2002 & $111 \%$ & $106 \%$ & $112 \%$ & $105 \%$ & $102 \%$ & $102 \%$ & $155 \%$ & $117 \%$ \\
\hline & 2003 & $108 \%$ & $103 \%$ & $111 \%$ & $105 \%$ & $107 \%$ & $102 \%$ & $106 \%$ & $108 \%$ \\
\hline & 2004 & $112 \%$ & $102 \%$ & $114 \%$ & $109 \%$ & $109 \%$ & $94 \%$ & $120 \%$ & $139 \%$ \\
\hline & 2005 & $110 \%$ & $109 \%$ & $99 \%$ & $120 \%$ & $114 \%$ & $105 \%$ & $128 \%$ & $84 \%$ \\
\hline & 2006 & $109 \%$ & $107 \%$ & $109 \%$ & $109 \%$ & $104 \%$ & $104 \%$ & $128 \%$ & $106 \%$ \\
\hline & 2007 & $113 \%$ & $110 \%$ & $106 \%$ & $108 \%$ & $114 \%$ & $109 \%$ & $110 \%$ & $98 \%$ \\
\hline & 2008 & $111 \%$ & $108 \%$ & $110 \%$ & $99 \%$ & $108 \%$ & $105 \%$ & $94 \%$ & $94 \%$ \\
\hline & 2009 & $112 \%$ & $107 \%$ & $104 \%$ & $105 \%$ & $112 \%$ & $100 \%$ & $97 \%$ & $111 \%$ \\
\hline & 2010 & $118 \%$ & $105 \%$ & $113 \%$ & $107 \%$ & $118 \%$ & $103 \%$ & $114 \%$ & $110 \%$ \\
\hline & 2011 & $120 \%$ & $110 \%$ & $122 \%$ & $107 \%$ & $113 \%$ & $106 \%$ & $128 \%$ & $127 \%$ \\
\hline & 2012 & $110 \%$ & $112 \%$ & $117 \%$ & $112 \%$ & $102 \%$ & $108 \%$ & $114 \%$ & $113 \%$ \\
\hline & 2013 & $112 \%$ & $104 \%$ & $114 \%$ & $114 \%$ & $101 \%$ & $95 \%$ & $118 \%$ & $123 \%$ \\
\hline
\end{tabular}

CVD - cardiovascular diseases

Table 2. Proportion of cancer incidence and treated diabetes in the Ostrava district compared to the Czech Republic (Source: Institute of Health Information and Statistics of the Czech Republic)

\begin{tabular}{|c|c|c|c|c|c|c|c|}
\hline \multirow{2}{*}{\multicolumn{2}{|c|}{$\begin{array}{l}\text { Indicator } \\
\text { Gender }\end{array}$}} & \multicolumn{2}{|c|}{ Cancer diseases* } & \multicolumn{2}{|c|}{ Colon cancers* } & \multicolumn{2}{|c|}{ Diabetes $^{* *}$} \\
\hline & & Male & Female & Male & Female & Male & Female \\
\hline \multirow{13}{*}{ ‡ } & 2001 & $122 \%$ & $117 \%$ & $125 \%$ & $117 \%$ & $128 \%$ & $107 \%$ \\
\hline & 2002 & $116 \%$ & $106 \%$ & $120 \%$ & $88 \%$ & $130 \%$ & $113 \%$ \\
\hline & 2003 & $107 \%$ & $107 \%$ & $105 \%$ & $151 \%$ & $133 \%$ & $118 \%$ \\
\hline & 2004 & $107 \%$ & $105 \%$ & $134 \%$ & $124 \%$ & $129 \%$ & $118 \%$ \\
\hline & 2005 & $108 \%$ & $102 \%$ & $104 \%$ & $132 \%$ & $127 \%$ & $118 \%$ \\
\hline & 2006 & $95 \%$ & $110 \%$ & $109 \%$ & $78 \%$ & $131 \%$ & $123 \%$ \\
\hline & 2007 & $108 \%$ & $99 \%$ & $114 \%$ & $106 \%$ & $128 \%$ & $120 \%$ \\
\hline & 2008 & $109 \%$ & $98 \%$ & $133 \%$ & $137 \%$ & $123 \%$ & $115 \%$ \\
\hline & 2009 & $113 \%$ & $100 \%$ & $124 \%$ & $123 \%$ & $125 \%$ & $108 \%$ \\
\hline & 2010 & $116 \%$ & $102 \%$ & $136 \%$ & $109 \%$ & $130 \%$ & $117 \%$ \\
\hline & 2011 & $107 \%$ & $103 \%$ & $120 \%$ & $113 \%$ & $132 \%$ & $120 \%$ \\
\hline & 2012 & - & - & - & - & $141 \%$ & $132 \%$ \\
\hline & 2013 & - & - & - & - & $146 \%$ & $131 \%$ \\
\hline
\end{tabular}

${ }^{*}$ newly reported cases, ${ }^{* *}$ treated diabetics, - still not available

men exceeds the national average for the period 2006-2010. The trend of cancer incidence has been increasing during the last 30 years in the Czech Republic. On the contrary, cancer incidence in women was below the national average. Also noteworthy is the high incidence of colon and rectal cancers in men which in Ostrava is much higher than the national average. Colon and rectal cancers are the most common cancers in the Czech Republic and their prevalence and mortality exceeds both the European and the world average. A increasing trend (in concordance with the global trend) was confirmed for the prevalence of diabetes that highly exceeds the average prevalence in the Czech Republic. Every tenth man and almost every tenth woman in Ostrava is diabetic.

\section{Special Monitoring}

In response to the air pollution problem in Ostrava and the region, the government initiated and established a special monitoring system in the late nineties that was aimed at environmentalhealth monitoring with regard to the specifics of the region (5). It consisted of monitoring population health status, occupational and environmental conditions, partly based on evaluation of routinely collected data of mortality and morbidity, extended by other studies of various types (retrospective, cross-sectional, case-control, prevalence survey etc.) and duration (single or repeated projects). Summary evaluation of the results over the period of its duration (i.e. approximately 10 years), points to worse health status of the 
population in the region, compared to the rest of the country (in life expectancy, standardized mortality, mortality from cardiovascular diseases, cancers etc.), high percentage of occupational incapacity, changes of health status in the unemployed, high number of people addicted to drugs, and increased prevalence of risk factors for chronic non-communicable diseases in the Karviná district in 1994-1997, as compared to the population of the Czech Republic, and increased incidence of childhood leukaemia in 1983-1984 and 1990. Conversely, no association was found between the environmental risk factors (air pollution and density of traffic) and the prevalence of allergy.

Several studies were conducted on human exposure to organic compounds (PCB, PCDD, PCDF and PCB necropsy samples of OCP DDE and HCB in breast milk) that did not reveal increased burden of the population by these compounds.

Several studies were targeted at the relationship between the prevalence of allergic diseases and air pollution-e.g. a retrospective study of school children (1993-1994), annually repeated crosssectional studies in Ostrava (1996-1999), a case-control study in the Karviná district (1997) and prevalence study in Ostrava (2001). Data were collected by questionnaires targeted at parents, practitioners and medical specialists. The relationship between ambient environmental risk factors and prevalence of allergy was not confirmed, contrary to the relationship with indoor environmental factors. The prevalence of allergy in 17 year old male and female adolescents was $20.2 \%$ and $13.6 \%$, respectively (the common prevalence in developed countries is about $30 \%$ ). In children below 1 year of age atopic eczema predominated. The most frequent diagnoses were pollinosis and allergic rhinitis, asthma and atopic eczema. Genetic predisposition (57-63\% of allergic children), a high number of acute respiratory diseases in early childhood before age 5 and risk factors in the indoor environment are considered the most serious risk factors for allergies. Specialised allergy treatment in children starts late, often in an already fully developed stage of the disease. A comprehensive approach to early prevention of allergy has not yet been presented.

\section{National Monitoring}

In 1992, the Environmental Health Monitoring System was set up in the Czech Republic and implemented in the national health legislation (Resolution of the Government of the Czech Republic No. 369/1991, Act on Protection of Public Health No. 258/2000 Coll. as amended, Action Plan for Health Resolution of the Government of the Czech Republic No. 810/1998). The system is based on the collection and evaluation of data on environmental pollution and resulting health outcomes. It is divided into several sub-systems: monitoring of selected indicators of population health and ambient and indoor air quality is included in Subsystem I. Of its activities, the incidence of acute respiratory diseases (MONARO) was followed up among children and adults during 1994-2014, based on data of the initial treatment of patients with acute respiratory disease (6) from paediatricians and practitioners (in 2013, in Ostrava 5 paediatricians, 2 general practitioners). In total 8,372 persons were involved. Summary results (for three cities - Ostrava, Karviná and Brno) pointed out respiratory diseases of the upper airways as the most significant group of diagnoses in 2013 with the highest average proportion of population of all ages and cities $(75.7 \%)$, followed by influenza
(11.4\%), acute bronchitis (11.2\%), inflammation of the middle ear, sinusitis and mastoiditis $(0.9 \%)$ pneumonia $(0.6 \%)$ and asthma $(0.2 \%)$. The mean incidence of lower respiratory tract diseases was 24 cases per 1,000 children in Ostrava, compared to 34 cases per 1,000 children in Karviná and 21 cases per 1,000 children in Brno. Acute respiratory diseases are the most common group of diseases in the childhood (with maximum prevalence in preschool children). A higher long-term incidence of acute respiratory diseases excluding flu was detected in the age group of 1-5 years. The incidence was approximately double as compared to the age group of 6-14 years.In terms of trends, an initial distinct decrease of respiratory diseases between 1995-2003 was followed up by a more or less balanced state below the average of the entire study period (1995-2013) which was further followed by an increase in the age group of 1-5 years and a slight decline in older children and adolescents in 2013 (6).

Of the Ostrava population included into the questionnaire survey called HELEN, only $43.7 \%$ of respondets were satisfied with their health, 52.4\% underwent long-term follow-up by a physician, $67.4 \%$ regularly used medication, and $60.4 \%$ reported health disorders: over $35 \%$ reported hypertension in family history, $41 \%$ had increased levels of cholesterol, more than $40 \%$ of men and $30 \%$ of women were regular smokers, more than $30 \%$ of men reported regular consumption of alcohol. And about $46.7 \%$ reported lifestyle dissatisfaction (7). The results suggest that subjective well-being and health perception is missing among residents in Ostrava. Lifestyle is affected by unhealthy habits, difficult living conditions, and occupational and environmental conditions (7).

\section{International Projects}

Since 1992 international projects (e.g. The Project Silesia, CESAR-PHARE, INCO-Copernicus and PATY), implemented by the Regional Hygiene Station and its successor the Public Health Institute in Ostrava have significantly contributed to current understanding the health impacts of air pollution in the region (Table 3 ).

The Project Silesia (1992-1997), carried out in collaboration with the United States Environmental Protection Agency (US EPA), the Ministry of Environment and the Ministry of Health of the Czech Republic) was an international project of a regional character, focused on estimation of the effects of environmental pollution on the health of the population in the Northern Moravia and Silesia (8). Concerning public health, the project contributed primarily to an identification of a carcinogenic risk from industrial emissions (coke ovens) in Ostrava (9), providing the first comprehensive evaluation and subsequent confirmation of mutagenicity of ambient air in Ostrava. In the framework of the demonstration project Management of the air quality a 30-days study was conducted on volunteers (during October and November 1995) with the aim of personal monitoring of population exposure to polyaromatic hydrocarbons (PAH) in the ambient air in Ostrava $(10,11)$. In addition to personal monitoring, urine and blood samples were collected to evaluate the level of 1-(OH)-pyrene and to determinate DNA adducts. Concurrently the concentrations of $\mathrm{PM}_{2.5}$ in the ambient and indoor environment were measured. Based on a mean of 4 weeks night time exposure of persons the samples were divided into the 2 groups by location of the residence 
Table 3. Summary of studies on health impacts of air pollution in Ostrava

\begin{tabular}{|c|c|c|c|}
\hline Study (Source) & Exposure & Indicator of interest & Result \\
\hline $\begin{array}{l}\text { Project Silesia } \\
\text { (adult volunteers }-30 \text { persons) } \\
(10,11)\end{array}$ & $\begin{array}{l}\mathrm{PM}_{2.5}, \mathrm{PAH}, \mathrm{B}(\mathrm{a}) \mathrm{P}-4 \text {-week average, } \\
\text { personal monitoring }\end{array}$ & $\begin{array}{l}\text { Biomarkers of exposure: detection of } \\
\text { the DNA adducts and } 1-(\mathrm{OH}) \text {-pyrene } \\
\text { levels }\end{array}$ & $\begin{array}{l}\text { A demonstrable effect of these pol- } \\
\text { lutants on health; higher mutageneity } \\
\text { in areas with higher levels of air pol- } \\
\text { lution and in occupationally exposed } \\
\text { populations }\end{array}$ \\
\hline $\begin{array}{l}\text { CESAR PHARE } \\
\text { (children aged } 7-12 \text { years from } \\
6 \text { countries) } \\
(12-18)\end{array}$ & $\begin{array}{l}\mathrm{PM}_{10} / \mathrm{PM}_{2.5} \text { - annual average con- } \\
\text { centrations }\end{array}$ & $\begin{array}{l}\text { Symptoms, lung function, risk per- } \\
\text { ception, allergological and immuno- } \\
\text { logical parameters }\end{array}$ & $\begin{array}{l}\text { In summary for the entire study: } \\
\text { Some factors greatly increase the } \\
\text { risk: transport, indoor environment, } \\
\text { socio-economic factors, perinatal } \\
\text { complications; the relationship be- } \\
\text { tween } \text { PM }_{10} \text { and a decrease of lung } \\
\text { function was not proved }\end{array}$ \\
\hline $\begin{array}{l}\text { PATY } \\
\text { (meta-analyses of } 8 \text { studies including } \\
\text { CESAR PHARE) } \\
(23-30)\end{array}$ & $\begin{array}{l}\mathrm{PM}_{10} \text { - annual average concentra- } \\
\text { tions }\end{array}$ & Symptoms, lung function & $\begin{array}{l}\text { In summary for the entire study: } \\
\text { The positive relationship between } \\
\text { PM }_{10} \text { and some symptoms: phlegm, } \\
\text { hay fever, bronchitis, morning and } \\
\text { night cough; the relationship between } \\
\text { PM }_{10} \text { and asthma or decrease of lung } \\
\text { function was not proved }\end{array}$ \\
\hline $\begin{array}{l}\text { Programme Ostrava } \\
\text { Health status of children (born } \\
2001-2002 \text { in } 10 \text { paediatric centres } \\
\text { in Ostrava) (39) }\end{array}$ & k-PAH, VOC* & Symptoms & $\begin{array}{l}\text { Significant impact of air pollution on } \\
\text { morbidity of pre-school children in } \\
\text { Ostrava Radvanice and Bartovice }\end{array}$ \\
\hline $\begin{array}{l}\text { Molecular epidemiological study: } \\
\text { effect of air pollution on human } \\
\text { organism (volunteers, adult popula- } \\
\text { tion) } \\
(35,40)\end{array}$ & $\begin{array}{l}\text { k-PAH, VOC personal monitoring } \\
\text { and } \mathrm{PM}_{2.5} \text { and k-PAH stationary } \\
\text { monitoring }\end{array}$ & $\begin{array}{l}\text { Biomarkers of exposure - PAH-DNA } \\
\text { adducts; biomarkers of effects - } \\
\text { chromosomal aberrations, gene } \\
\text { expression, biomarkers of suscep- } \\
\text { tibility - genetic polymorphism of } \\
\text { selected genes }\end{array}$ & $\begin{array}{l}\text { Less significant changes than would } \\
\text { be based on the dose-response } \\
\text { effect, possibly adaptive response of } \\
\text { the organism to increased exposure; } \\
\text { increased levels of peroxidised lipids }\end{array}$ \\
\hline
\end{tabular}

*VOC - volatile organic compounds

of persons in the city. Of the total number of examined urine samples $(\mathrm{N}=98) 37 \%$ showed a mutagenic effect. In areas with a higher exposure load $\left(\mathrm{PM}_{2.5} 47 \mu \mathrm{g} / \mathrm{m}^{3}\right.$, B(a)P $\left.3.8 \mathrm{ng} / \mathrm{m}^{3}\right)$ a nearly twofold number of mutagenic samples was detected compared to the number of samples from areas with a lower exposure load $\left(\mathrm{PM}_{2.5} 34.8 \mu \mathrm{g} / \mathrm{m}^{3}, \mathrm{~B}(\mathrm{a}) \mathrm{P} 2.8 \mathrm{ng} / \mathrm{m}^{3}\right)$. Profiles of detected adducts in the environmentally exposed population (RAL 0.7-8.0) were very similar to adducts found in coke oven workers (RAL 0.9-18.1). The majority of examined urine samples contained 1-(OH)-pyrene, suggesting exposure to PAHs (10).

The EU research project CESAR (1994-1997), conducted in collaboration with the Czech National Institute of Public Health, the Netherlands National Institute for Public Health and the Environment (RIVM), the Agricultural University in Wageningen, and the London School of Hygiene and Tropical Medicine (LSHTM) was focused on air pollution and respiratory illnesses in children aged $7-11$ years $(12-18)$. The project was implemented in several Central European countries including the Czech Republic (Ostrava). In total 22,809 children (about 4,000 per country) participated in the project, making it one of the largest studies of air pollution and respiratory health in the world. It was also the first research project of this type conducted in the Czech Republic (18).

In Ostrava, the city was divided into four areas with different levels of air pollution ( 3 polluted study areas and one control area, considered as a clean area). The project consisted of air quality measurement (October 1995-October 1996; 1,789 samples - mean and range of study-area specific annual average concentrations of $\mathrm{PM}_{10}: 75(63-91) \mu \mathrm{g} / \mathrm{m}^{3} ; \mathrm{PM}_{2.5}: 52$ (49-60) $\mu \mathrm{g} / \mathrm{m}^{3}, \mathrm{SO}_{2}: 15(13-17)$ $\left.\mu \mathrm{g} / \mathrm{m}^{3} ; \mathrm{NO}_{2}: 11(10-12) \mu \mathrm{g} / \mathrm{m}^{3}\right)$ health questionnaire study $(3,672$ questionnaires), lung function measurement (1,753 examinations) immunological study (528 blood samples, 80 questionnaires for immune biomarkers study, 221 questionnaires of specific $\operatorname{IgE}$ study, 76 questionnaires on vaccination of children), and risk perception study (716 questionnaires, 14 semi-structured interviews with stakeholders, focus group discussion with parents). Questionnaires were focused primarily on risk factors (quality of housing, smoking, physical activity, dietary habits, socioeconomic factors) related to the prevalence of respiratory disorders $(14,18,43)$.

No statistically significant differences between $\mathrm{PM}_{10}$ concentrations in the study areas were detected. The project was evaluated as a summary of the overall findings, i.e. a summary of all countries (19-22). The following factors were associated with a significantly increasing health risk - traffic, indoor air quality, perinatal complications, achieved level of education and related professions, smoking, unemployment and social benefit registration. Reduced lung function or immunity in relation to $\mathrm{PM}_{10}$ exposure or systemic difference between the frequency of respiratory disorders in children from polluted and clean areas was not confirmed, as expected.

Subsequently, the CESAR project data was further analysed in other EU projects - INCO-Copernicus (1998-2000) focused on multi-level data modelling and PATY (Pollution and the Young, 2002-2004) (23-30). The PATY project was a meta-analysis of 
the 12 cross-sectional studies from Europe (CESAR - Czech Republic (Ostrava), Hungary, Poland and the Slovak Republic, Germany - the study Bitterfeldt, Hettstedt and Zerbst, Netherlands - the 24-schools study, Austria - the Linz study) and the USA (a study of the 24 North American cities) dealing with children's respiratory diseases and air pollution. Results are available mostly as summarized analyses of data from the whole project (18).

Meta-analysis based on the questionnaires $(59,256$ children in 132 study areas from the 13 countries) confirmed the association between the concentrations of $\mathrm{PM}_{10}$ and cough prevalence (25) and the concentrations of $\mathrm{NO}_{2}$ and the prevalence of inhalant allergies $(25,26)$, but not the association between $\mathrm{PM}_{10}$ concentrations and asthma prevalence. However, the results of individual studies showed heterogeneity, that could not be explained by the specific differences (e.g. Eastern vs. Western countries, the season, specific year, response-rate or the air pollution measurement method used) (18).

Out of the all areas involved in the PATY project the highest values of the following respiratory symptoms were in Ostrava: wheezing, awakening due to wheezing, the prevalence of bronchitis, phlegm, night cough and sensitivity to inhaled allergens. Ostrava reported the second highest values of all participating areas in prevalence of symptoms of night and morning cough. Ostrava was again ranked the worst region of all in the PATY project in terms of the highest prevalence of respiratory symptoms related to $\mathrm{PM}_{10}$ exposure (25).

Neither INCO-Copernicus nor PATY project found a consistent relationship between lung function and annual average concentrations of $\mathrm{PM}_{10}$. However, a significant heterogeneity between the results of individual studies when assessing changes in pulmonary function was detected.

In studies implementing lung function measurements, the effects of $\mathrm{PM}_{10}$ on pulmonary function were negative, statistically significant, but increased in studies carried out in spring or summer season as opposed to winter. This finding indicates an association between a lung function and summer smog (18, $28,29)$.

\section{Study of Morbidity and Mortality and Other Studies}

Over the past twenty years, various individual studies and projects of different scope and duration have been conducted, analysing health impacts of environmental pollution on ad hoc basis. The results of many interesting small studies have either not been published or have been published in journals without an impact factor or are still under consideration for publication. Many institutions have been active in this field - e.g. the Public Health Institute, Ostrava in the framework of regional projects and the process of health risk assessment (31-33), the National Institute of Public Health, Prague in the panel study focused on the prevalence of allergy in relation to air pollution (34), and the Academy of Sciences assessing the genotoxicity of air in Ostrava and evaluating the health status of the population as discussed in detail in the other article in this supplement (35).

An earlier pilot study focused on the prevalence of allergies in relation to air pollution used a geographic information system for evaluation $(36,37)$. The data on the prevalence of allergies in Ostrava were obtained from national monitoring data of the Czech Republic in 1998. The study included a total of 577 patients aged
5, 9 and 13 years belonging to three paediatric districts. Detailed information on the child patients and their allergies were obtained from questionnaires completed by parents and paediatricians. Three areas have been identified, one square kilometre each covering the majority of patients $(\mathrm{N}=457)$.

Logistic regression models were used to determine the influence of various factors on the prevalence of allergies, adjusted for the study area, gender, age and family history, and extended for factors of outdoor and indoor environment. Exposure data on selected pollutants (TSP, $\mathrm{SO}_{2}, \mathrm{NO}_{\mathrm{x}}$ a NO emissions from traffic) in ambient air were defined using dispersion models of mean annual concentrations. The results confirmed the relationship between family history, gender, age and factors of the indoor environment. Conversely, no association was found between the prevalence of allergy and air pollution $(\mathrm{OR}=0.97,95 \% \mathrm{CI} 0.40-2.34)$.

A panel study Asthma Exacerbations and Symptom Variability in Children Due to Short-term Ambient Air Pollution Changes in Ostrava covering the period of November 2013 to February 2014 investigated the association between short-term elevations of air pollutant concentrations and exacerbation of respiratory problems, use of asthma medication and restriction of daily activities in asthmatic patients in Ostrava (147 patients aged 6-18 years with a confirmed diagnosis of mild to moderate persistent asthma) based on daily diaries, measurement of outdoor concentrations of $\mathrm{PM}_{10}, \mathrm{NO}_{2}$ and $\mathrm{SO}_{2}$ and estimated daily exposures in different environments (home and at school) (42). These results suggest moderately strong associations between air pollutant concentrations and respiratory difficulties among asthmatic children and adolescents (combined for wheezing and/or difficulty in breathing, per $10 \mu \mathrm{g} / \mathrm{m}^{3}$ increase in the mean 24-h exposure were $1.07(95 \%$ confidence interval 1.04-1.11) for $\mathrm{PM}_{10}, 1.30$ (1.18-1.44) for $\mathrm{NO}_{2}$, and 1.37 (1.18-1.59) for $\mathrm{SO}_{2}$ ). Use of an additional inhaler (in addition to usual medication) was also more frequent during higher air pollutant concentrations (42).

The Institute of Public Health in Ostrava has implemented a number of studies quantifying estimated of $\mathrm{PM}_{10}$ concentrations on mortality and morbidity in recent years. In the first study the impact of $\mathrm{PM}_{10}$ on mortality and morbidity of the Ostrava population during unusually long smog episodes in 2010 comparing to 2009 was estimated (total mortality, hospitalization for cardiac and respiratory causes, incidence of lower respiratory tract symptoms in healthy children and adults with a chronic respiratory disease and the number of days with restricted activity) (31). Estimates indicated the possibility of up to a two-fold proportion of cases caused by increased concentrations of $\mathrm{PM}_{10}$ than in 2009. In 2010, during the first two months, air pollution could contribute up to $4.3 \%$ of all deaths, $23 \%$ of lower respiratory tract symptoms in children and $20.5 \%$ of days with restricted activity. Comparison among study areas in Ostrava based on an estimated proportion of cases showed heterogeneity within the city.

The correlation study "The relationship between $\mathrm{PM}_{10}$ and specific mortality and hospitalizations in Ostrava" analyzed the association of monthly concentrations of $\mathrm{PM}_{10}$ and selected health indicators based on the routine data from the Institute of Health Information and Statistics for the years 2007 and 2009 (32). The analysis confirmed significant correlations between deaths for respiratory diseases, deaths for cardiovascular diseases and hospitalization for respiratory diseases in the 25-59 age group, and $\mathrm{PM}_{10}$ concentrations. 
The subsequent "Study of mortality and morbidity from cardiovascular and respiratory causes in relation to $\mathrm{PM}_{10}$ air pollution within the city of Ostrava" carried out in 2013-2014 analyzed the daily $\mathrm{PM}_{10}$ air pollution data in relation to the daily numbers of deaths and hospitalization from cardiovascular and respiratory causes in Ostrava hospitals (33). This study revealed no connection between $\mathrm{PM}_{10}$ and cardiovascular and respiratory mortality. For cardiovascular hospitalization and concentrations of $\mathrm{PM}_{10} \mathrm{a}$ relationship was found but after adjustment for other influencing factors this relationship was no longer statistically significant. The relationship between hospitalization for respiratory causes and $\mathrm{PM}_{10}$ concentrations up to $150 \mu \mathrm{g} / \mathrm{m}^{3}$ remained statistically significant even after adjustments for other factors.

\section{DISCUSSION AND CONCLUSION}

In the city of Ostrava and the region numerous projects and studies were conducted over the past 20 years focusing on the impact of environmental pollution (air pollution) on health. Based on their results it can be concluded, that the state of the environment in the city Ostrava and the region has been affecting the health status of the population in term of an increased overall mortality and morbidity comparing with a not exposed population.

This state can be considered a significant inequality in access to health. Recent findings also show that in the whole country life expectancy is increasing, but a more detail analysis points out that it is a life extension in a disease, rather than a prolongation of a life in health for which even a slight decline was recorded. This is therefore rather an evidence of achieved quality of a medical care, than a major achievement of public health policy in recent years. Such a situation is in the direct opposite of the situation in other Western European, especially Scandinavian countries, where the achieved prolongation of life expectancy was practically identical, but in good health, not in a disease (38). This adverse state is associated with significant economic costs for the provision of health care and represents a societal problem. These costs further increase in the case of the excessive increase of morbidity and mortality.

Due to the incoherent and inconsistent way of monitoring of different indicators by using various methods at different times, thus it is so far not possible to assess more precisely the complexity of environmental pollution on health in Ostrava and the region. It is known, that the effectiveness and sustainability of applying public health measures must be based on high quality epidemiological studies and underlying analyses. A simple comparison of incidence or mortality data obtained from the routine statistics and measured concentration of pollutants cannot adequately assess the impact of environmental pollution including air pollution on health because of the absence of evaluation of other interacting risk factors that are not taking into account. Only high level quality epidemiological studies (e.g. a cohort study) may help to determine sufficiently an extent of environmental disease burden. The indisputable advantage of such kind of studies is also the fact that they can be focused on subclinical manifestations (genotoxicity, mutagenicity, etc.) of air pollution effects. In contrast with Prague and Brno, in Ostrava, a cohort has not yet been established, allowing follow up the health status of a certain population group in Ostrava over time, in spite of its long-term pollution.
Environmental health impact of the air pollution in Ostrava and in the region is one of the priority areas in the Health 2020 - National Strategy for the health protection and promotion and disease prevention that is a policy framework initiating efficient mechanisms to improve health of the population in the Czech Republic, sustainable in the long-term (38). Current involvement of universities, government institutions, Academy of Sciences in the environmental health research together with the emphasis and concern on inter-institutional and international co-operation makes a good constellation and timing for an objective assessment of health status of population related to environmental burden in the city Ostrava and the region. It is recommended to conduct a prospective epidemiological study as the best approach to investigating health status of the population.

\section{REFERENCES}

1. Przybylova B, Barcuch A. Ostrava. Praha: NLN, Nakladatelství Lidové noviny; 2013. (In Czech.)

2. Drbal C. Changes in development of health determinants, their nature, manifestations and impact on health policy. Zdrav Čes Repub. 2000;3(12):6-12.(In Czech.)

3. Air quality maps of Europe. Air quality data: Air Base - EEA [Internet]. Copenhagen: European Environment Agency; 2014 [cited 2015 July 29]. Available from: http://www.eea.europa.eu/data-and-maps/figures/ particulate-matter-pm10-annual-limit-value-for-the-protection-ofhuman-health-7.

4. Czech Health Statistics Yearbook [Internet]. Praha: ÚZIS ČR; 1992-2014 [cited 2015 Jul 19]. Available from: http://www.uzis.cz/category/edice/ publikace/rocenky.

5. Šlachtová H, Fejtková P, Skýbová D. Special Environmental Health monitoring in the Ostrava-Karviná region. Report 1994-2003. Ostrava: Zdravotní ústav se sídlem v Ostravě, Krajská hygienická stanice Moravskoslezského kraje v Ostravě; 2004. (In Czech.)

6. Environmental health monitoring system in the Czech Republic. Subsystem 1. Airborne pollution and associated health risks. Report 2013. Praha: SZÚ; 2014 [cited 2015 Jul 19]. Available from: http://www.szu. cz/uploads/documents/chzp/odborne_zpravy/OZ_13/ovzdusi_2013.pdf. (In Czech.)

7. Environmental health monitoring system in the Czech Republic. Subsystem 6. Health assessment - study HELEN. Report 2005. Praha: SZÚ; 2006 [cited 2015 Jul 19]. Available from: http://www.szu.cz/uploads/ documents/chzp/odborne_zpravy/OZ_05/Helen_05.pdf. (In Czech.)

8. Č́ižková H. Project Silesia: practical application of methods of risk assessment and management. Ochr Ovzduší. 1998;10(2):4-6. (In Czech.)

9. Česlová V, Michalík J, Volf J. Evaluation of the health risk of emissions from coke plants for the health of the Ostrava population. Hygiena. 2002;47(2):63-72. (In Czech.)

10. Williams RW, Watts RR, Hartlage AT, Phillips L, Lewtas J, Dobias L, et al. Ostrava human exposure and biomarker study. EPA/600/R-97/069. Washington DC: U.S. Environmental Protection Agency, Office of Research and Development; 1997.

11. Dobiáš L, Kůsová J, Havránková J, Vít M, Volf J, Rakusová R, et al. Personnel exposure of the Ostrava population by polycyclic aromatic hydrocarbons in the ambient air (thirty-days monitoring study, project Silesia. Ochr Ovzduší. 1998;10(2):11-15. (In Czech.)

12. Antova T, Pattenden S, Nikiforov B, Leonardi GS, Boeva B, Fletcher $\mathrm{T}$, et al. Nutrition and respiratory health in children in six Central and Eastern European countries. Thorax. 2003;58(3):231-36.

13. Gorog K, Pattenden S, Antova T, Niciu E, Rudnai P, Scholtens S, et al. Maternal smoking during pregnancy and childhood obesity: results from the CESAR study. Matern Child Health J. 2011;15(7):985-92.

14. Houthuijs D, Breugelmans O, Hoek G, Vaskövi É, Miháliková E, Pastuszka JS, et al. PM10 and PM2.5 concentrations in Central and Eastern Europe: results from the CESAR study. Atmos Environ. 2001;35(15):2757-71.

15. Šlachtová H, Avdičová M, Tvrdík J, Fletcher T, Dusseldorp A, Kolarova $\mathrm{D}$, et al. Perceptual differences regarding health and environmental prob- 
lems and their remedies in two states of the former Czechoslovakia. Cent Eur J Public Health. 2003;11(1):44-9.

16. Šlachtová H, Tomášek I, Jones K, Vašina B, Volf J. Risk perception study in the framework of PHARE/CESAR study - Central European study on air pollution and respiratory health: risk perception, the environment, and communication strategies in the CESAR project: results from the Czech Republic. J Hazard Mater. 1998;61(1-3):313-17.

17. Timová S, Leonardi GS, Hrubá F, Lochman I, Lochmanová A, Erdei E et al. Immune system parameters in children of Central and Eastern Europe: the CESAR study. Cent Eur J Public Health. 2004;12(3):119-25.

18. Šlachtová H, Kůsová J. The health effects of air pollution in the OstravaKarviná region. Ochr Ovzduší. 2008;21(5-6):24-32. (In Czech.)

19. Lvončík S, Šplíchalová A, Tomášková H, Tomášek I, Tvrdík J, Volf J. Multilevel comparison of selected results from the CESAR/PHARE study - national results from the Czech Republic - impact of selected factors to respiratory health. Epidemiology. 1998;9(4):S161.

20. Fabiánová E, Fletcher T, Brunekreef B, Houthuijs D, Lebret E, Leonard GS, et al. CESAR: respiratory symptoms and indoor risk factors. Epidemiology. 1999;10(4):S30.

21. Nikiforov B, Breugelmans O, Brunekreef B, Fletcher T, Houthuijs D, Jazwiec-Kanyion B, et al. CESAR: respiratory health. Epidemiology. 1999;10(4):S29.

22. Houthuijs D, Antova T, Brunekreef B, Fletcher T, Koppova K et all. Traffic and respiratory symptoms in Central and Eastern Europe: results from the CESAR study. Epidemiology. 2001;12(4):S44.

23. Antova T, Pattenden S, Brunekreef B, Heinrich J, Rudnai P, Forastiere F, et al. Exposure to indoor mould and children's respiratory health in the PATY study. J Epidemiol Community Health. 2008;62(8):708-14.

24. Gehring U, Pattenden S, Slachtova H, Antova T, Braun-Fahrländer C, Fabianova E, et al. Parental education and children's respiratory and allergic symptoms in the Pollution and the Young (PATY) study. Eur Respir J. 2006;27(1):95-107

25. Hoek G, Pattenden S, Willers S, Antova T, Fabianova E, Braun-Fahrländer C, et al. PM10, and children's respiratory symptoms and lung function in the PATY study. Eur Respir J. 2012;40(3):538-47.

26. Pattenden S, Hoek G, Braun-Fahrländer C, Forastiere F, Kosheleva A, Neuberger M, et al. NO2 and children's respiratory symptoms in the PATY study. Occup Environ Med. 2006;63(12):828-35.

27. Slachtova H, Gehring U, Hoek G, Tomaskova H, Luttmann-Gibson H, Moshammer H, et al. Parental education and lung function of children in the PATY study. Eur J Epidemiol. 2011; 26(1):45-54.

28. Fletcher T, Pattenden S, Antova T, Braun-Fahrländer Ch, Koppova K, Forastiere $\mathrm{F}$, et al. Consistency and heterogeneity in PM10 and NO2 effects on children's respiratory symptoms. Epidemiology. 2005;16(5):S93-4.

29. Fletcher T, Pattenden S, Hoek G, Heinrich J, Neuberger MA, Braun $\mathrm{CH}$, et al. PM10 and respiratory symptoms in primary school children in multi-country study. Epidemiology. 2004;15(4):S32.
30. Moshammer H, Hoek G, Luttmann-Gibson H, Neuberger MA, Antova, T, Gehring U, et al. Parental smoking and lung function in children: an international study. Am J Respir Crit Care Med. 2006;173(11):1255-63.

31. Tomášková H, Tomášek I, Šlachtová H, Šebáková H. Impact assessment of PM10 concentrations on mortality and morbidity in Ostrava during smog episodes. Hygiena. 2011;56(1):5-10. (In Czech.)

32. Tomášková H, Šlachtová H, Tomášek I, Skýbová D, Šebáková H. Relationship PM10 pollution and specific mortality and hospitalizations in Ostrava in the period 2007 and 2009. In: Proceedings of the 19th Conference Environment and Health; 2011 Sep 19-21; Smokovec, SK. Bratislava: Úrad verejného zdravotníctva SR; 2012. (In Czech.)

33. Tomášek I, Tomášková H, Polaufová P, Šplíchalová A, Michalík J. The study of mortality and morbidity from cardiovascular and respiratory causes in relation to PM10 air pollution in Ostrava. Report 2014. Ostrava: Zdravotní ústav se sídlem v Ostravě; 2014. (In Czech.)

34. Environmental health monitoring system in the Czech Republic. Subsystem 6. Health assessment, study HELEN - Allergic diseases in children. Report 2012. Praha: SZÚ; 2013 [cited 2015 Jul 19]. Available from: http:// www.szu.cz/uploads/documents/chzp/alergie/Subsystem_6_OZ_2013_2. pdf. (In Czech.)

35. Šrám RJ. Results of air pollution study - new knowledge 2010. Ochr Ovzduší. 2010;22(5-6):3-7. (In Czech.)

36. Michalík J, Šlachtová H, Polášková M. Evaluation of outdoor factors in prevalence of allergies using the GIS. Epidemiology. 2000;11(4):S74.

37. Michalík J, Šlachtová H, Tomášková H. GIS in medicine. GEOinfo. 2001; 8(1):20-2. (In Czech.)

38. Health 2020 - national strategy for health protection and promotion and disease prevention. Prague: Ministry of Health of the Czech Republic; 2014.

39. Dostál M, Šrám RJ. The study on the health status of children from Ostrava-Radvanice and Ostrava-Bartovice. Ochr Ovzduší. 2010;22(56):35-8. (In Czech.)

40. Rössner P, Švecová V, Šrám RJ. The impact of air pollution on the levels of markers of oxidative stress. Ochr Ovzduší. 2010;22(5-6):38-43. (In Czech.)

41. Rössnerová A, Špátová M, Rössner P, Nováková Z, Solanský I, Šrám RJ. Factors affecting the frequency of micronuclei in asthmatic children from Ostrava. Ochr Ovzduší. 2010;22(5-6):44-9. (In Czech.)

42. Velická H, Puklová V, Keder J, Brabec M, Malý M, Bobák M, et al Asthma exacerbations and symptom variability in cildren due to shortterm ambient air pollution changes in Ostrava. Cent Eur J Public Health. 2015;23(4):292-8.

43. Central European Study on Air pollution and Respiratory health: study results. Brussels: European Commission; 1997.

Received August 28, 2015 Accepted in revised form June 22, 2016 